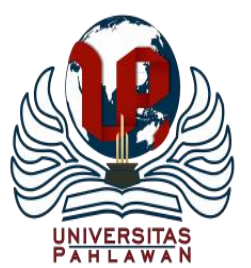

Jurnal Basicedu Volume 5 Nomor 1 Tahun 2021 Halaman 140-150

JURNAL BASICEDU

Research \& Learning in Elementary Education

https://jbasic.org/index.php/basicedu

\title{
Implementasi Pendidikan Multikultural Dilihat dari Perspektif Guru, Kepala Sekolah dan Kegiatan Siswa di Sekolah Dasar
}

\author{
Sulistyani Puteri Ramadhani' ${ }^{1}$, Arita Marini' $^{2}$, Arifin Maksum ${ }^{3}$ \\ Universitas Trilogi ${ }^{1}$, Universitas Negeri Jakarta ${ }^{2}$,Universitas Negeri Jakarta ${ }^{3}$ \\ Email: $\underline{\text { sulistyani@ trilogi.ac.id }}^{1} \underline{\text { aritamartini@unj.ac.id }}^{2} \underline{\text { arifinmaksum@unj.ac.id }}^{3}$
}

\begin{abstract}
Abstrak
Penelitian ini bertujuan untuk melihat implementasi multiukultural di SDS Yasporbi 1. Penelitian ini menggunakan pendekatan kualitatif. Karateristik partisipan penelitian meliputi kepala sekolah, guru-guru sebanyak 4 orang di SDS Yasporbi 1 Jakarta Selatan. Teknik pengumpulan data dengan wawancara semi terstruktur, dan analisis data dilakukan dengan menggunakan analisis tematik. Penelitian ini mengungkapkan 4 (empat) tema yaitu upaya guru untuk implementasi pendidikan multikultural, perspektive kepala sekolah penerapan multikultural; proses kegiatan pembelajaran di kelas multikultural; proses kegiatan ekstrakulikuler. Hasil penelitian ini menunjukkan bahwa secara umum keempat partisipan, yaitu guru kelas tinggi, guru kelas rendah, kepala sekolah, guru agama yang memiliki pengalaman yang berbeda di dalam pelaksanaan multikultural yang dialami partisipan.
\end{abstract}

Kata kunci: pendidikan, multikultural, sekolah dasar, kualitiatif

\section{Abstract}

This study aims to see the multicultural implementation in SDS Yasporbi 1. This study uses a qualitative approach. The characteristics of the research participants included the principal and teachers as many as 4 people at SDS Yasporbi 1, South Jakarta. The data collection technique used semi-structured interviews, and data analysis was performed using thematic analysis. This study reveals 4 (four) themes, namely the teacher's efforts to implement multicultural education, the perspective of the principal of multicultural application; the process of learning activities in multicultural classrooms; extracurricular activities process. The results of this study indicate that in general the four participants, namely high class teachers, low class teachers, principals, religious teachers who have different experiences in multicultural implementation experienced by participants.

Keywords: education, multicultural,elementary school, qualitative

Copyright (c) 2021 Sulistyani Puteri Ramadhani, Arita Marini, Arifin Maksum

$\triangle$ Corresponding author :

Address : Jl. Taman Makam Pahlawan No 1 Kalibata Jakarta Selatan ISSN2580-3735 (Media Cetak)

Email : sulistyani@trilogi.ac.id

ISSN 2580-1147 (Media Online)

Phone : 081210339004

DOI : $\quad$ https://doi.org/10.31004/basicedu.v5i1.618 
141 Implementasi Pendidikan Multikultural Dilihat Dari Perspektif Guru, Kepala Sekolah Dan Kegiatan Siswa di Sekolah Dasar- Sulistyani Puteri Ramadhani, Arita Marini, Arifin Maksum

DOI : https://doi.org/10.31004/basicedu.v5i1.618

\section{PENDAHULUAN}

Dalam kenyataannya di dalam kehidupan masyarakat di negara Indonesia penuh dengan perbedaan ras, agama, suku, budaya, dan bahasa, karena Indonesia merupakan negara dengan ciri khas unik yang beragam. Namun dengan perbedaan (Raihani, 2012) yang terjadi munculnya persoalan di tengah masyarakat Indonesia terkait isu tentang perbedaan suku, agama, ras dan budaya antar kelompok, tawuran antar siswa, sikap anak didik di sekolah adanya bullying dengan kawan sekolah yang memperlihatkan perbedaan yang terjadi di tengah kebersamaan dalam perbedaan yang telah ada dibangun oleh para leluhur terdahulu bangsa.

Konflik yang terjadi menjadikan adanya diskriminasi diantara kelompok. Konflik ini tidak bisa hanya dilihat saja, dan dibiarkan terjadi, terlebih khusus pada siswa sekolah dasar. Sekolah merupakan sarana pendidikan yang tepat mengenalkan perbedaan multikultural. Menurut (Setyono \& Widodo, 2019) dapat diartikan pada penekanan pendidikan multikultural lebih di tekankan pada siswa di sekolah yang semestinya di bimbing dan dibiasakan untuk memahami jenis perbedaan yang terjadi dikehidupan sosial bermasyarakat seperti agama, ras budaya, dan bahasa.

Saat proses pembelajaran, guru memberikan iklim yang membentuk multiculture oriented yang memfokuskan keadilan sosial dan budaya bagi siswa, sehingga guru perlu melakukan transformasi diri menuju pribadi yang multikultur dan mempunyai desain pembelajaran yang berbasis multikultur yang tidak berorientasi pada nilai kognitif saja. Lebih lanjut riset (Fietzer, Mitchell, \& Ponterotto, 2018) menunjukkan bahwa dengan pendidikan multikulturalisme harus diterapkan dalam proses pembelajaran melalui proses pembiasaan, pembelajaran multikultural dilakukan dengan pembentukan sikap, pola pikir, tindakan, dan pembiasaan sehingga muncul kesadaran nasional keindonesiaan.

Karakter keindonesiaan yang perlu dimiliki siswa seperti memahami perbedaan antar suku, budaya bahasa dan ras yang terjadi di lingkungan sosial. (Amir, 2013) Terwujudnya karakter keindonesiaan menjadikan landasan yang kuat sebagai ciri dari masyarakat Indonesia yang bersinergi. Kekuatan dari sifat keindonesiaan ini menjadi energi besar untuk menjadi Indonesia sebagai bangsa besar di tengah bangsa-bangsa di negara lain. Bangsa besar hanya dapat diwujudkan melalui karakter manusia yang kuat. Karakter keindonesiaan melalui pendidikan multikulturalisme inilah salah satu harapan menuju Indonesia besar di masa depan.

Lebih lanjut penelitian dari (Mahiri, 2017) bahwa dikatakan hasil risetnya yaitu implementasi pendidikan multikultural melalui pembelajaran yang dilakukan oleh guru serta interaksi kehidupan bersosial yang perlu dilakukan oleh siswa dalam lingkungan sekolah. Sementara itu penelitian (Piland \& Barnard, 2017) menunjukkan bahwa melalui sekolah, guru dapat menanamkan konsep dari multikulturalisme dan pluralistis bagi siswa, guru perlu menunjukkan secara kreatif dalam memberikan arahan untuk mamahami dan menerima perbedaan yang terjadi sebagai bentuk keberhasilan pendidikan multikultural. 
Penelitian ini dilakukan ditargetkan mengenai implementasi pelaksanaan pendidikan multikultural yang telah dilakukan beberapa peneliti sebelumnya. Melalui studi pustaka terdahulu yang menjunjukkan melalui pendidikan multikultural dapat dipahami oleh masing-masing siswa sekolah dasar. Bentuk dari pendidikan multikultual melalui sekolah. Sekolah yang dipilih dari penelitian ini yaitu SDS Yasporbi 1 Jakarta Selatan.

Sekolah Yayasan Yasporbi 1 Jakarta Selatan adalah sekolah swasta yang dimiliki oleh Bank Indonesia yang mempunyai tujuan untuk mencerdaskan generasi bangsa. Sekolah Yasporbi I Jakarta Selatan adalah sekolah swasta umum yang menyediakan program pendidikan sesuai dengan kurikulum dari Diknas. Kurikulum untuk tingkat SD menggunakan kurikulum K-13 yang dikembangkan melalui dengan mengintegrasaikan Ilmu Pengetahuan dan Teknologi (IPTEK) dengan peningkatan Keimanan dan Ketakwaaan (IMTAK), dimana prosesnya dilakukan pada setiap pelajaran.

Keunggulan Sekolah Yasporbi 1 yaitu menerima murid dari berbagai multikultur suku, agama dan ras dari dalam negeri ataupun luar negeri. Pendidikan multikultural berlangsung sangat penting dalam masyarakat multikultural karena dapat melayani memberdayakan kolektif yang terpinggirkan dan memobilisasi kegiatan sosial sebagai bentuk penerimaan perbedaan. Pendidikan multikultural di SDS Yasporbi 1 Jakarta Selatan sebagian besar terkait dengan agama dan suku yang berbeda-beda.
Dalam penelitian ini dilibatkan Ibu Kepala Sekolah yaitu Ibu Intan, dan 4 orang guru yang terdiri dari guru kelas rendah: Ibu Indah, kelas tinggi: Ibu Nur, guru Agama Hindu, guru Ekstra kulikuler. Penelitian ini bertujuan untuk mendeskripsikan dan menganalisis bagaimana implementasi pendidikan multikultural di SDS Yasporbi 1 Jakarta Selatan. Peneltiian ini dengan menggunakan observasi, wawancara semi terstuktur, dan dokumentasi.

\section{METODE}

Memuat metodologi yang digunakan dalam penelitian deskriptif kualitatif. Pengertiannya (Syahrum, 2012) di dalam penelitian deskriptif yaitu, suatu bentuk penelitian yang ditujukan untuk mendeskripsikan fenomena-fenomena yang ada, baik fenomena alamiah maupun fenomena buatan manusia. Fenomena itu bisa berupa bentuk, aktivitas, karakteristik, perubahan, hubungan, kesamaan, dan perbedaan antara fenomena yang satu dengan fenomena lainnya (Lijan Poltak Sinambela, 2014). Penelitian deskriptif merupakan penelitian yang berusaha mendeskripsikan dan menginterpretasikan sesuatu, misalnya kondisi atau hubungan yang ada, pendapat yang berkembang, proses yang sedang berlangsung, akibat atau efek yang terjadi, atau tentang kecendrungan yang tengah berlangsung.

Penelitian deskriptif menurut (Siyoto, 2015) adalah penelitian yang dirancang untuk memperoleh informasi tentang status suatu gejala saat penelitian dilakukan. Lebih lanjut dijelaskan, dalam penelitian deskriptif tidak ada perlakuan yang diberikan atau dikendalikan serta tidak ada 
uji hipotesis sebagaimana yang terdapat pada penelitian eksperiman.

Metode deskriptif menurut (Sugiyono, 2014) adalah pencarian fakta dengan interpretasi yang tepat. Penelitian deskriptif mempelajari masalah masalah dalam masyarakat, serta tata cara yang berlaku dalam masyarakat serta situasi-situasi tertentu, termasuk tentang hubungan, kegiatankegiatan, sikap-sikap, pandangan-pandangan serta proses-proses yang sedang berlangsung dan pengaruh-pengaruh dari suatu fenomena.

Metode penelitian menurut (Patilima, 2017) yang digunakan peneliti dalam penelitian ini adalah pendekatan kualitatif dengan metode deskriptif. Metode penelitian yang digunakan adalah metode kualitatif. Metodologi adalah proses, prinsip, dan prosedur yang kita gunakan untuk mendekati problem dan mencari jawaban.

Pada penelitian ini yaitu dengan metode penelitian kualitatif merupakan suatu penelitian yang digunakan untuk meneliti pada objek yang alamiah dimana peneliti adalah sebagai instrumen kunci, teknik pengumpulan data dilakukan secara gabungan, analisis data bersifat induktif, dan hasil penelitian kualitatif lebih menekankan makna daripada generalisasi.

\section{HASIL DAN PEMBAHASAN}

Pendidikan multikultural dapat dikatakan (Banks, 2014) sebagai ide, gerakan reformasi pendidikan, pada proses yang tujuan utamanya adalah mengubah struktur lembaga pendidikan sehingga laki-laki dan siswa perempuan, siswa luar biasa, dan siswa yang merupakan anggota dari beragam ras, kelompok etnis, bahasa, dan budaya akan memiliki kesempatan yang sama untuk meraih prestasi akademis di sekolah.

Perlu untuk mengkonseptualisasikan sekolah sebagai sistem sosial untuk mengimplementasikan pendidikan dengan multikultural supaya berhasil. Setiap variabel utama di sekolah, seperti budayanya, hubungan kekuatannya, kurikulum dan materinya, serta sikap dan sikapnya keyakinan guru harus diubah dengan cara yang akan memungkinkan untuk siswa dari berbagai kelompok. Untuk mengubah sekolah, pendidik harus memiliki pengetahuan tentang pengaruh tersebut kelompok tertentu tentang perilaku siswa.

\section{Sekilas tentang SDS Yasporbi 1 Jakarta Selatan}

SDS Yasporbi 1 Jakarta Selatan berada di wilayah Pancoran Jakarta Selatan. SDS Yasporbi 1 Jakarta Selatan menerima siswa dari macam agama, suku, budaya dan etnis. Berdasarkan data dari kepala sekolah, total siswa di SDS Yasporbi 1 Jakarta Selatan Tahun 2020 sebanyak 450 siswa, yang terdiri dari berbagai agama, mayoritas di sekolah SDS Yasporbi 1 Jakarta Selatan menganut agama Islam sebesar 80\%, Agama Hindu 8\%, Agama Kristiani 6\%, Agama Budha 4\%, dan Agama Khatolik 2\%. Berdasarkan data dari kepala sekolah SDS Yasporbi 1 Jakarta Selatan juga memiliki siswa yang beragam suku. Mayoritas suku pada siswa SDS Yasporbi 1 Jakarta Selatan Berasal dari Jawa sebesar 68\%, Sumatera Utara $8 \%$, Sumatera Selatan 6\%, Papua 4\%, Kalimantan 5\%, Sulawesi 5\%, Bali 5\%, dan NTT 5\%.

SDS Yasporbi 1 Jakarta Selatan mencerminkan keragaman yang terus tumbuh. Pada tahun 2019 SDS Yasporbi 1 Jakarta Selatan 
menerima kerjasama dari suku papua sebanyak 20 siswa yang tersebar dari seluruh kelas. Keberagaman dari suku, agama dan etnis di SDS Yasporbi 1 Jakarta merupakan dasar bagi sekolah sebagai penciri keunikan sekolah. Jumlah siswa dari latar belakang suku, agama dan etnis yang berbeda memiliki dengan peningkatan keteraturan dan frekuensi. Dengan masuknya demokrasi, masalah keragaman, multikultural pendidikan, dan pelatihan guru menjadi hal yang baik dalam pendidikan.

\section{Implementasi Multikulturan di Kelas Rendah}

\section{1-2-3 Saat Pembelajaran}

Hasil observasi dari guru kelas rendah bahwa implementasi pendekatan kontribusi di kelas pada siswa SD kelas bawah (kelas I, II, III) implementasi pendidikan multikultural dapat dilakukan dengan pendekatan kontribusi, antara lain dengan cara: siswa secara bersama-sama memperkenalkan beragam bentuk rumah dan baju adat dari etnis yang berbeda dari masing-masing daerah siswa. Guru mengajak siswa untuk mencicipi makanan yang berbeda dari berbagai daerah secara bergantian sesuai dengan latar belakang daerah siswa. Siswa juga diajak untuk mendengarkan lagu-lagu daerah lain oleh gurunya.

Siswa juga bisa menunjukkan cara berpakaian yang berbeda, baik dari suku bangsa maupun dari negara lain disesuaikan dengan latar belakang yang berbeda. Memperkenalkan tokohtokoh pejuang dari berbagai daerah dalam dan luar negeri. Guru bersama siswa juga dapat menunjukkan tempat dan cara beribadah yang berbeda. Guru dapat meminta siswa yang berbeda etnis untuk menceritakan tentang uparaca perkawinan di keluarga luasnya. Siswa juga dapat memperkenalkan beberapa kosakata penting yang berasal dari suku bangsa atau negara (ras) lain. Misalnya: matur nuwun (Jawa), muliate (Batak), thank you (Inggris), kamsia (Cina). Siswa juga dapat memperkenalkan panggilan untuk laki-laki dan perempuan. Misalnya, amang (bapak) upik (Minangkabau), ujang (Sunda), koko (Cina), dan sebagainya. Substansi pendidikan multikultural pada tahap ini adalah menanamkan pada siswa bahwa manusia yang hidup di sekitarnya, di tempat lain, dan di dunia ini sangat beragam. Sebenarnya semua nilainya sama. Sama-sama rumah, makanan, lagu, pakaian, tokoh ibadah, perkawinan, maksud kata dan sebagainya.

Dengan demikian, siswa mulai mengerti bahwa ada cara yang berbeda, tetapi maksud dan nilainya sama sehingga dapat belajar untuk menerima perbedaan dengan proses rasa yang menyenangkan. Akhirnya, siswa merasa berbeda bukanlah masalah, melainkan anugerah.

\section{Implementasi Multikulturan di Kelas Tinggi 4-}

\section{5-6 Saat Pembelajaran}

Hasil observasi dan wawancara oleh guru kelas tinggi yaitu implementasi pendidikan multikultural di kelas siswa SD kelas (IV, V, VI) sudah mulai mampu memahami makna dari pendekatan multikultural tepat untuk diberikan, seperti: melalui pembelajaran dengan metode diskusi pada kelompok-kelompok kecil. Melalui diskusi siswa bisa bertukar pikiran dengan siswa lainnya demikian pula dengan guru. Bahan diskusi merupakan materi pendidikan agama itu sendiri. 
Guru mengkondisikan diskusi dengan menyediakan sumber-sumber yang tak terbatas atau menugaskan siswanya untuk menemukan kasus yang aktual yang ada di lingkungan sekitar mereka.

Kedua penumbuhan kepekaan dalam diri siswa terhadap informasi, terutama yang berkaitan dengan isu-isu masalah yang berkaitan dengan masalah yang berkaitan dengan masyarakat multikultural. Sebab di dalamnya terdapat perbedaan ethno-cultural dan agama, demokrasi dan pluralitas, kemanusiaan universal dan subyek lain yang relevan. (Mirzon Daheri, Juliana, Deriwanto, 2020)

Ketiga, memberikan gambaran tentang paradigma kepada siswa sikap saling menghormati, tulus dan toleransi terhadap keanekaragaman budaya yang hidup di tengahtengah masyarakat, dengan memperkuat basik spiritual yang peka terhadap masalah-masalah sosial keagamaan.

Keempat, Siswa kelas 4-5-6 juga dapat membaca buku-buku cerita rakyat dari berbagai daerah dan negara lain yang telah disediakan perpustakaan oleh sekolah. Memutarkan CD tentang kehidupan di pedesaaan, di perkotaan, dari daerah dan negara yang berbeda. Menceritakan pengetahuan dan pengalaman guru tentang materi di daerah atau negara lain.

$$
\text { Mengintegrasikan nilai-nilai dari }
$$
multikultural dan menerapkannya di kelas. Hal tersebut dilakukan untuk menanamkan pengetahuan yang luas bagi siswa. Rasa ketertarikan akan keragaman yang diperoleh di dalam kelas akan memotivasi siswa untuk tahu lebih banyak dengan membaca, melihat di internet, berkunjung, bertanya kepada orang yang lebih tahu, dan sebagainya.

\section{Peran Guru dalam Pembelajaran Multikulturalisme}

Kutipan dari hasil wawancara oleh guru memberikan informasi bahwa dengan wawasan yang luas tentang keragaman budaya, kehidupan, persahabatan, dan pengetahuan, siswa akan tumbuh menjadi orang inklusif, mudah menerima perbedaan, toleran, dan menghargai orang lain. Selain itu, ia juga akan mudah berinteraksi dengan lingkungan yang baru ataupun yang kompleks. Dalam mengimplementasikan pendidikan multikultural di kelas banyak bergantung pada peran dan kemampuan guru.

Ada beberapa petunjuk yang dapat membantu guru disesuikan juga dengan (Mahfud, 2016), antara lain sebagai berikut: sensitiflah dengan sikap, perilaku rasial, stereotipe, prejudice, labelling dari guru dan pernyataan yang anda buat tentang kelompok etnis lain. Hindarilah pernyataan seperti orang Cina pelit, orang Jawa manutan, siswa kelas bawah memang sulit maju, dan sebagainya. Perluaslah pengetahuan guru juga harus didalami dengan kehidupan masyarakat lain yang berbeda latar belakang etnis, agama, jenis kelamin, dan status sosial ekonomi. Hal ini sangat diperlukan guru untuk lebih efektif dengan pendekatan multikultural.

Guru juga membawa citra positif tentang berbagai perbedaan. Hal ini dapat dilakukan dengan kegiatan nyata, seperti majalah dinding, poster, dan kalender yang memperlihatkan 
perbedaan ras, gender, agama, dan status sosial ekonomi sehingga siswa terbiasa melihatnya. Guru juga harus sensitiflah pada perilaku dan sikap siswa yang berbeda. Guru juga membimbing dan yakinkan siswa agar dapat menerima perbedaan sebagai hal wajar dan anugerah yang memperkaya budaya manusia. Media dalam penyampaian pesan dalam perbedaan dapat menggunakan buku, film, vidio, $\mathrm{CD}$, dan rekaman untuk melengkapai buku teks agar dapat memperkaya pengetahuan siswa tentang keragaman budaya yang ada di masyarakat di tanah air ataupun di dunia.

Hal ini juga disampaikan oleh (Raihani, 2012) bahwa guru kelas menginformasikan bahwa ciptakanlah berbagai iklim kepada siswa dengan memberi siswa kesempatan untuk menceritakan pengalaman pribadi tentang budaya mereka ataupun budaya lain yang mereka ketahui. Guru juga memberikan informasi bahwa gunakanlah teknik belajar kooperatif dan kerja kelompok untuk meningkatkan integrasi sosial di kelas dan di sekolah.

Guru multikultural yang efektif secara aktif memperkenalkan keragaman budaya dan menanggapinya di dalam ruang kelas melalui model-model pembelajaran yang melibatkan seluruh siswa dari berbagai latar belakang dan pengalaman. Penanaman nilai-nilai multikultural dalam kehidupan beragama seharusnya tidak berhenti pada upaya-upaya yang dilakukan sekolah dalam mengenalkan siswa kepada keberagamaan yang sudah menjadi keniscayaan dalam kehidupan, tetapi siswa juga perlu mampu menghayati dan memahami akan pentingnya nilai-nilai multikultural dalam kehidupan ini.
Multikultural di Indonesia bersifat budaya antar etnis yang kecil, yaitu budaya antar suku bangsa. Keragaman budaya datang dari dalam bangsa Indonesia sendiri. Oleh karenanya, pendidikan multikultural menekankan pentingnya akomodasi hak setiap kebudayaan dan masyarakat sub-nasional untuk memelihara dan mempertahankan identitas kebudayaan dan masyarakat nasional. Sehingga dalam penerapannya sangat diperlukan adanya sikap toleransi, cinta damai, dan jujur (Herawani, 2019).

\section{Perspektif Guru sebagai Akomodator}

Hasil wawancara dari guru kelas bahwa dikatakan guru melihat diri mereka sebagai akomodator, mereka cenderung membuat modasi dalam pengajaran mereka untuk memfasilitasi pembelajaran bagi siswa beragam. Guru cenderung menunjukkan rasa adil tidak membeda-bedakan terhadap para semua siswa yang beragam sehingga guru memberikan contoh langsung dalam proses pembelajaran. Siswa juga menganggap diri mereka saling menghargai dalam perbedaan. Guru agama juga memberikan informasi bahwa ruang kelas itu memiliki minat dan perkembangan anak sebagai komitmen utamanya, bukan pelestarian budaya dominan, yang dipandang sebagai persaingan dengan budaya mikro lainnya. Peran guru bukanlah sebagai membedakan budaya, tetapi bahwa seorang pendidik, teman, sehabat bagi pelajar, yang sedang dalam perjalanan menuju pengembangan diri dan realisasi diri.

Untuk mendidik siswa secara efektif dari berbagai latar belakang, guru harus pertama-tama harus memahami kemanusiaan dan identitas 
budayanya, dan kemudian pergi ke langkah berikutnya untuk menegaskan kemanusiaan siswa di dalamnya ruang kelas, serta menegaskan identitas budaya masing-masing. Dalam urutan untuk mencapai tujuan ini, siswa meluangkan waktu untuk meneliti warisan budaya mereka sendiri juga pengaruh budaya lain yang telah membuat mereka menjadi diri mereka sendiri. Mereka menuliskan latar belakang dari perbedaan suku, budaya dan ras yang dapat mewakili budaya mereka. Ini dibagikan dengan seluruh kelas, dan ini berakhir.

\section{Perspektif Kepala Sekolah terhadap Konsep Pendidikan Multikultural}

Hasil wawancara dari kepala sekolah menyatakan bahwa prinsip-prinsip pengembangan model pendidikan karakter berbasis multikultural terimplementasikan ke dalam perilaku keteladanan para guru yang memiliki pengaruh kuat pada diri peserta didik. Guru hendaknya bertindak sebagai role mode, suri teladan bagi kehidupan sosial akademis siswa, baik di dalam maupun di luar kelas. Pendidikan karakter berbasis multikultural memiliki semangat mengakui dan menghargai perbedaan-perbedaan kultural dan kontribusikontribusinya terhadap cara hidup masyarakat. Upaya terpenting dalam menerapkan pendidikan semacam ini adalah melalui pengajaran yang responsif secara kultural. Di sinilah pentingnya peran guru dalam pengembangan model pendidikan karakter tersebut. Ditambahkan dari uraian kepala sekolah bahwa pengajaran responsif secara kultural (culturally responsive teaching) merupakan pengajaran yang mengakui dan mengakomodasi keragaman kultural di dalam ruang kelas.

Sekolah (Ibrahim, 2008) mengedepankan nilai-nilai multikultural dalam upaya membina karakter siswa dan menerapkan model pembelajaran yang bersifat responsif, karena pengajaran yang bersifat responsif secara cultural mencakup hal-hal sebagai berikut, yaitu: 1) menciptakan lingkungan kelas yang positif di mana seluruh siswa dihargai dan dihormati, 2) mengomunikasikan harapan-harapan yang positif untuk pembelajaran seluruh siswa, 3) mengakui keragaman kultural dalam diri siswa dan mengintegrasikan keragaman ini ke dalam kurikulum, 4) cara agar guru dan pendidik lainnya dapat meningkatkan peluang mereka untuk keberhasilan pendidikan.

Pendidikan multikultural (Yaya Suryana, 2015) juga merupakan gerakan reformasi yang mencoba mengubah sekolah dan lembaga pendidikan lainnya sehingga peserta didik dari semua kelas sosial, jenis kelamin, ras, bahasa, dan kelompok budaya akan memiliki kesempatan yang sama untuk belajar. Pendidikan dari multikultural melibatkan perubahan total sekolah atau lingkungan pendidikan.

Sekolah juga memberikan kontribusi dalam penerapan pendidikan multikultural, yaitu dengan: 1) menyiapkan guru yang berkualitas dan memahami benar tentang berbedaan dari suku yang beragam dari siswa, 2) sarana yang diberikan sekolah juga harus mendukung proses pembelajaran siswa dengan keberagaman, misalkan saat siswa bermain basket dengan teman yang beragam, dari kegiatan bermain bersama 
siswa juga dapat memahami dari latar belakang siswa sehingga terbiasa dalam perbedaan yang terjadi, 3) mengarahkan kepada guru dalam pembuatan RPP yaitu dengan memberikan gambaran di setiap pertemuan melakukan diskusi kecil dari setiap keberagaman siswa, dan pasti nya menggunakan metode yang inovatif untuk menunjang pelaksanaan pembelajaran yang maximal, 4) sarana dari kegiatan keagamaan: di sekolah SDS Yasporbi 1 Jakarta Selatan menganut agama yang beragam ada yang Hindu, Islam, Budha, Kristen dan juga Katolik sehingga kepala sekolah memberikan kualitas SDM dari masingmasing guru agama yang akan diajarkan oleh siswa, 5) Kegiatan ekstrakulikuler yang beragam dimulai dari kegiatan tari tradisional, yang memberikan pemahaman kebudayaan bagi siswa yang beraneka ragam, kegiatan ekstrakulikuler olah raga seperti basket, futsal, menggambar dan renang sehingga memberikan ruang yang cukup luas bagi siswa dalam memahami perbedaan tersebut.

Pembinaan karakter siswa dengan model intrakurikuler ditekankan dalam proses-proses pembelajaran Pendidikan Agama baik di dalam ruang kelas maupun di luar ruang kelas. Namun, yang penting untuk dicermati ialah bahwa program intrakurikuler untuk pembinaan karakter siswa dirancang sedemikian rupa dengan mengintegrasikan nilai-nilai karakter tertentu ke dalam Rencana Pelaksanaan Pembelajaran. Guru sangat berkepentingan untuk menciptakan suasana dan lingkungan kelas yang membuat seluruh siswa merasa dihargai sehingga memunculkan harapanharapan positif.

\section{UCAPAN TERIMA KASIH}

Ucapan terima kasih saya haturkan untuk Kepala Sekolah Yasporbi 1 Jakarta Selatan yaitu Ibu Intan selaku koresponden dalam penelitian ini. Peran Ibu Bekti juga saya ucapkan terimakasih atas informasinya. Ucapan terima kasih kepada rekan-rekan guru lain nya dalam membeirkan waktu luang kepada peneliti untuk diberikan keterangan untuk kelayakan peneltiian yang telah dituliskan peneliti.

\section{SIMPULAN}

Pendidikan multikultural adalah ide, gerakan reformasi pendidikan, dan proses yang tujuan utamanya adalah mengubah struktur lembaga pendidikan sehingga laki-laki dan siswa perempuan, siswa luar biasa, dan siswa yang merupakan anggota dari beragam ras, kelompok etnis, bahasa, dan budaya akan memiliki kesempatan yang sama untuk meraih prestasi akademis di sekolah. Perlu untuk mengkonsepkan sekolah sebagai sistem sosial untuk mengimplementasikan agar pendidikan multikultural berhasil. Setiap variabel utama di sekolah seperti budayanya, hubungan kekuatannya, kurikulum dan materinya, serta sikap dan sikapnya keyakinan staf harus diubah dengan cara yang akan memungkinkan sekolah untuk mempromosikan kesetaraan nasional untuk siswa dari berbagai kelompok. Untuk mengubah sekolah, pendidik harus memiliki pengetahuan tentang pengaruh tersebut kelompok tertentu tentang perilaku siswa.

Sekolah Dasar SDS Yasporbi 1 Jakarta Selatan memberikan kultur sekolah yang sehat 
149 Implementasi Pendidikan Multikultural Dilihat Dari Perspektif Guru, Kepala Sekolah Dan Kegiatan Siswa di Sekolah Dasar- Sulistyani Puteri Ramadhani, Arita Marini, Arifin Maksum DOI : https://doi.org/10.31004/basicedu.v5i1.618

perlu dibangun dengan jalan menumbuhkan rasa bangga dengan sekolah, menjalin komunikasi efektif di antara warga sekolah, mensosialisasikan visi dan misi sekolah dengan berulang-ulang dan beragam media, mengadakan kegiatan bersama yang melibatkan kerjasama guru dan siswa. Manejemen sekolah yang dilandasi tujuan pendidikan multikultural mensyaratkan kepala sekolah sebagai pemimpin (leader) daripada sekedar manajer, yaitu pemimpin yang peka terhadap perubahan dan kemendesakan, menciptakan koalisi, dan menancapkan pendekatan baru dalam budaya sekolah agar siswa yang berasal dari latar belakang sosial, ekonomi dan budaya yang kurang beruntung dapat mencapai kesuksesan dalam belajar. Proses pembelajaran yang berpegang pada prinsip multikultural didasarkan pada pedagogik transformatif, yaitu pedagogik yang mengungkapkan kebebasan dan keterbatasan manusia sekaligus mengakui dirinya adalah makhluk Tuhan Yang Maha Esa. Pembelajaran menekankan pada kerja sama, toleransi, saling menghormati dan sukses bersama.

\section{DAFTAR PUSTAKA}

Amir. (2013). Pendidikan karakter berbasis empati pada anak-anak usia sd, (1), 83-91.

Banks. (2014). An Introduction to Multicultural Education. Boston: Allyn Bacon.

Fietzer, A. W., Mitchell, E., \& Ponterotto, J. G. (2018). Multicultural Personality and Multicultural Counseling Competency in Counselor Trainees. Counselor Education and Supervision, 57(2), 82-97. https://doi.org/10.1002/ceas.12095

Herawani, nellly. H. dan Y. F. (2019). Jurnal basicedu. Jurnal Basicedu, 3(2), 524-532.
Ibrahim, R. (2008). Pendidikan Multikultural: Upaya Meminimalisir Konflik dalam Era Pluralitas Agama. El-Tarbawi, 1(1), 115127.

https://doi.org/10.20885/tarbawi.vol1.iss1.art 9

Lijan Poltak Sinambela. (2014). Metodologi Penelitian Kualitatif. Yogyakarta: Graha Ilmu.

Mahfud, C. (2016). Pendidikan Multikultural. Yogyakarta: Pustaka Pelajar.

Mahiri, J. (2017). Introduction: multicultural education and micro-cultural youth. Multicultural Education Review, 9(2), 79-82. https://doi.org/10.1080/2005615X.2017.1313 022

Mirzon Daheri, Juliana, Deriwanto, A. D. A. (2020). Jurnal basicedu. Jurnal Basicedu, $3(2)$,

524-532. https://doi.org/10.31004/basicedu.v4i4.445

Patilima, H. (2017). Metode Penelitian Kualitatif. Jakarta: Alfa.

Piland, W. E., \& Barnard, B. (2017). Multicultural Education in the Classroom. Community College Journal of Research and Practice, 20(1), 49-63. https://doi.org/10.1080/1066892960200106

Raihani. (2012). Report on multicultural education in pesantren. Compare, 42(4), 585-605. https://doi.org/10.1080/03057925.2012.6722 55

Setyono, B., \& Widodo, H. P. (2019). The representation of multicultural values in the Indonesian Ministry of Education and Culture-Endorsed EFL textbook: a critical discourse analysis. Intercultural Education, 30(4), 383-397. https://doi.org/10.1080/14675986.2019.1548 102

Siyoto, S. (2015). Dasar Penelitian Metodologi. Sleman, Yogyakarta: Literasi Media Publishing.

Sugiyono. (2014). Metode Penelitian Pendidikan Pendekatan Kuantitatif, Kualitatif, dan R\&D. 
150 Implementasi Pendidikan Multikultural Dilihat Dari Perspektif Guru, Kepala Sekolah Dan Kegiatan Siswa di Sekolah Dasar- Sulistyani Puteri Ramadhani, Arita Marini, Arifin Maksum DOI : https://doi.org/10.31004/basicedu.v5i1.618

Bandung: Alfabeta.

Syahrum. (2012). Metodelogi Penelitian Kulitattif dan Kuantitatif. Bandung: Cita Pustaka Media.

Yaya Suryana, R. (2015). Pendidikan Multikultural. Bandung: CV. Pustaka Setia. 